\title{
Towards an understanding of the evolutionary role of fire in animals
}

\author{
Juli G. Pausas ${ }^{1}$, Catherine L. Parr ${ }^{2,3}$
}

Final version of this manuscript at: Evolutionary Ecology (2018)

https://doi.org/10.1007/s10682-018-9927-6

Abstract Wildfires underpin the dynamics and diversity of many ecosystems worldwide, and plants show a plethora of adaptive traits for persisting recurrent fires. Many fire-prone ecosystems also harbor a rich fauna; however, knowledge about adaptive traits to fire in animals remains poorly explored. We review existing literature and suggest that fire is an important evolutionary driver for animal diversity because (1) many animals are present in fire-prone landscapes and may have structural and phenotypic characters that contribute to adaptation to these open landscapes; and (2) in some cases, animals from fire-prone ecosystems may show specific fire adaptations. While there is limited evidence on morphological fire adaptations in animals, there is evidence suggesting that different behaviors might provide a rich source of putative fire adaptations; this is because, in contrast to plants, most animals are mobile, unitary organisms, have reduced survival when directly burnt by fire and can move away from the fire. We call for research on fire adaptations (morphological, behavioral, and physiological) in animals, and emphasize that in the animal kingdom many fire adaptations are likely to be behavioral. While it may be difficult to discern these adaptations from other animal behaviors, making this distinction is fundamental if we want to understand the role of fire in shaping biodiversity. Developing this understanding is critical to how we view and manage our ecosystems in the face of current global and fire regime changes.

Keywords Adaptations $\cdot$ Behavioral traits $\cdot$ Evolutionary fire ecology $\cdot$ Fire-fauna

\footnotetext{
* Juli G. Pausas

juli.g.pausas@ext.uv.es

1 CIDE-CSIC, Ctra. Naquera Km. 4.5, 46113 Montcada, Valencia, Spain

2 School of Environmental Sciences, University of Liverpool, Liverpool L69 3GP, UK

${ }^{3}$ Department of Animal, Plant and Environmental Sciences, University of the Witwatersrand, Private Bag X3, Wits 2050, South Africa
} 


\section{Introduction}

It is now well known that fire is an intrinsic and natural process in many ecosystems (Pausas and Keeley 2009). Yet while plants have a plethora of adaptive traits that enable then to persist under recurrent fires (Keeley et al. 2011, 2012), understanding of how fauna has responded to fire is much more limited (Parr and Chown 2003). There is a rich fauna occurring in fire-prone ecosystems that has evolved under frequent fires, therefore it is likely that this recurrent and predictable disturbance has influenced the evolution of fauna. However, the evolutionary role of fire on animals remains inadequately explored (Fig. 1), and this gap in knowledge has cascading effects on how we view and manage our ecosystems.

Different fire responses are expected to evolve in animals and plants (in terrestrial ecosystems) due to their intrinsic differences in mobility and modularity. Plants are rooted (i.e., immobile) and modular; they cannot easily escape from fires but can survive with a reduced number of modules. This has allowed the evolution of structural traits for in situ persistence (survival and population persistence; Pausas et al. 2004; Keeley et al. 2011). There are also some plants that rely on seed dispersal (the mobile phase of plants) for postfire recolonization from neighbor populations (exogenous regeneration), although they are not common in most fire-prone ecosystems. Most terrestrial animals are mobile and unitary organisms (colonies that function as a superorganism, such as those of ants and termites, may be a notable exception); survival and persistence is negatively affected if they are burnt, although they have the capacity to move away from the fire. Consequently, behavioral traits to avoid fires are expected to be particularly important in animals in flammable environments. However, if demonstrating that some structural traits in plants are the response to a history of fire is challenging (Keeley et al. 2011), disentangling the

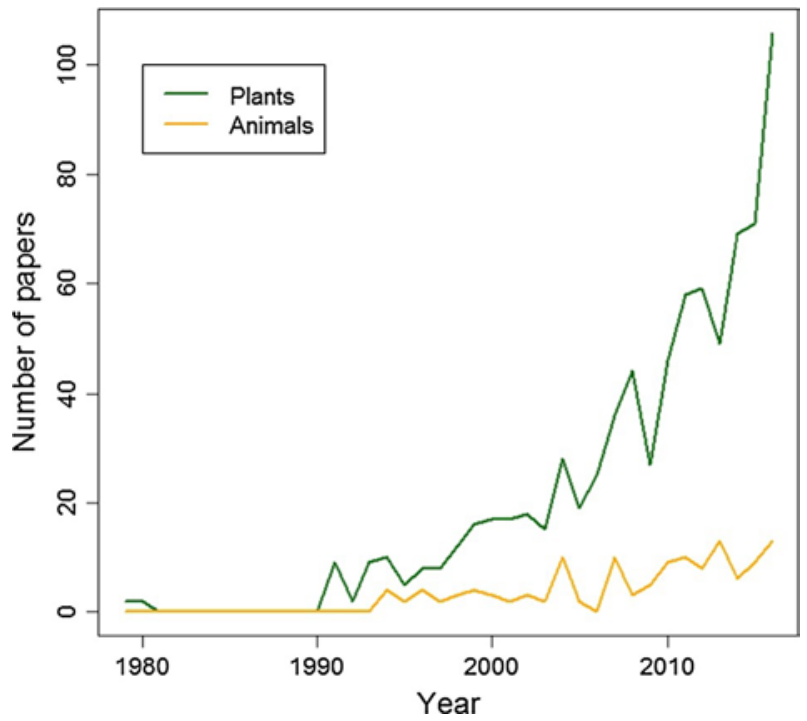

Fig. 1 Number of papers published on the evolutionary fire ecology of plants (green line; upper line) and animals (orange line; lower line) during the recent years. Data based on the number of papers in the Science Citation Index Expanded that matched the following searches: for plants: "fire AND (plants OR vegetation) AND evolution*”; for animals: "fire AND (animals OR fauna OR wildlife) AND evolution* NOT 'fire ant*,, 
role of fire from the role of other enemies (predators) in shaping fire avoiding behavior in animals is even harder; yet this is fundamental if we aim to understand the role of fire in shaping biodiversity.

There are many papers and several reviews (e.g. Whelan 1995; Smith 2000; Swengel 2001; Whelan et al. 2002; New 2014; van Mantgem et al. 2015; Bowman et al. 2016) on the ecological responses of fauna to fire, including postfire successional studies and studies of animal communities under different fire regimes. They depict a reorganization of animal communities in response to fire, with positive and negative responses, depending on the species, fire characteristics, and recovery speed of the system. Our aim is not to summarize these studies but to highlight that fires are an important evolutionary driver for understanding animal biodiversity. To do so we briefly compile evidence suggesting that there are animals well adapted to fire-prone ecosystems, that is, to the habitat generated by recurrent fires; yet although they require fires for survival (fire-dependent animals), they do not necessarily show any specific morphological adaptation to fire. There are also a few documented cases of animals with traits that can be considered shaped by fire (fireadapted fauna). However, research on the evolutionary aspects of the fire-fauna relationship is still in its infancy, and many of the putative adaptations have not been rigorously tested. Here we aim to stimulate further research in this potentially fruitful area to fill a gap in understanding biodiversity drivers (Table 1). Developing this understanding is critical in the face of the current rapid global changes, which certainly include fire regime changes (mostly increasing in size and intensity, although it depends on the ecosystem; see Keeley and Syphard 2016; Schoennagel et al. 2017; Chergui et al. 2018).

\section{Fauna adapted to fire-prone habitats}

There are many animals present in fire-prone landscapes and they have structural and phenotypic traits that contribute to adaptation to this habitat; that is, they benefit from the habitat generated by recurrent fires (Table 2). In some instances, they may be quite specialized in the sense that they require fire to create the appropriate conditions for growth and reproduction. Although these species may not show any apparent adaptation to survive or to avoid fire, their population size increases after fire, i.e., they are adapted to the

Table 1 Some key questions for improving our understanding of the evolutionary role of fire in animals

\begin{tabular}{|c|c|}
\hline Scale/approach & Question \\
\hline $\begin{array}{l}\text { Among closely- } \\
\text { related taxa }\end{array}$ & $\begin{array}{l}\text { Can taxa (or populations) in fire-prone habitats detect, avoid and survive fire better } \\
\text { than those in non-fire prone areas, and if so, how? }\end{array}$ \\
\hline Population & To what extent are fire-related behavioural traits variable and heritable? \\
\hline Population & $\begin{array}{l}\text { To what extent have fire regime changes (e,g., fire exclusion, increased fire } \\
\text { frequency, lengthened fire season) generated evolutionary shifts in these } \\
\text { behavioural traits? i.e. how labile are these traits? }\end{array}$ \\
\hline Population & Are (post-fire) colonization traits under strong selection in fire landscape mosaics? \\
\hline Population & $\begin{array}{l}\text { What fitness benefit is conferred by the use of fire directly or postfire habitats for } \\
\text { species without any apparent fire-adaptation? }\end{array}$ \\
\hline Community & $\begin{array}{l}\text { Does the prevalence of species with behaviour that confer fire protection (e.g., } \\
\text { burrowing behaviour) differ under contrasting fire regimes? }\end{array}$ \\
\hline
\end{tabular}


Table 2 Example of the possible benefits to animals of fire and fire-altered habitat

\begin{tabular}{|c|c|c|}
\hline Benefit & Category & Fauna [references] \\
\hline Fresh grasses, and leaves & $\begin{array}{l}\text { Food } \\
\text { resource }\end{array}$ & $\begin{array}{l}\text { Herbivores, e.g., large mammalian grazers, insect } \\
\text { herbivores, arboreal marsupials }[1,2]\end{array}$ \\
\hline $\begin{array}{l}\text { Fire-released seed, and more } \\
\text { exposed seeds in the soil }\end{array}$ & $\begin{array}{l}\text { Food } \\
\text { resource }\end{array}$ & Granivores including rodents, seed-removing ants [3] \\
\hline Animals fleeing or dying & $\begin{array}{l}\text { Food } \\
\text { resource }\end{array}$ & Predators, scavengers (e.g., birds, kites, owls, ants) \\
\hline Weakened and dead trees & $\begin{array}{l}\text { Food } \\
\text { resource }\end{array}$ & $\begin{array}{l}\text { Bark beetles, cavity-dependent (hollow-nesting) } \\
\text { animals like woodpeckers, other birds, lizards, } \\
\text { possums [4] }\end{array}$ \\
\hline Dead wood & $\begin{array}{l}\text { Food } \\
\text { resource }\end{array}$ & Saproxylic insects [5-7] \\
\hline Flowers, post-fire blossom & $\begin{array}{l}\text { Food } \\
\text { resource }\end{array}$ & Insect pollinators [12-15], hummingbirds [16] \\
\hline Meeting point & Mating cue & $\begin{array}{l}\text { Saproxylic insects [8,9], smoke flies [10], mole crickets } \\
\text { [22] }\end{array}$ \\
\hline $\begin{array}{l}\text { Synchronization of the } \\
\text { emergence }\end{array}$ & Mating cue & Insects (some beetles; [11]) \\
\hline $\begin{array}{l}\text { Reduced habitat complexity: } \\
\text { increased visibility }\end{array}$ & $\begin{array}{l}\text { Habitat } \\
\text { alteration }\end{array}$ & $\begin{array}{l}\text { Birds of prey; large herbivores, primates (easier to } \\
\text { move and detect their predators [17]); }\end{array}$ \\
\hline $\begin{array}{l}\text { Reduced habitat complexity: } \\
\text { movement through the } \\
\text { environment }\end{array}$ & $\begin{array}{l}\text { Habitat } \\
\text { alteration }\end{array}$ & $\begin{array}{l}\text { Grouse (gaps for mating; [18]), seed-dispersing ants } \\
\text { (move further with fire [19]) }\end{array}$ \\
\hline Microclimate change & $\begin{array}{l}\text { Habitat } \\
\text { alteration }\end{array}$ & $\begin{array}{l}\text { Ectotherms-e.g. thermophilous reptiles, insects [20] } \\
\text { (warmer post-fire environment) }\end{array}$ \\
\hline Reduction of parasites & $\begin{array}{l}\text { Biotic } \\
\text { interactions }\end{array}$ & Vertebrates [21] \\
\hline Reduction of predators & $\begin{array}{l}\text { Biotic } \\
\text { interactions }\end{array}$ & Insects (e.g., reduction of insectivore vertebrates) [23] \\
\hline
\end{tabular}

By benefits (first column) we refer to the changes in resources and conditions generated by fire that can be used by the fauna groups mentioned (third column), and are aggregated in four categories (second column): Changes in food resources, mating cues, habitat alterations, and changes in biotic interactions. Note that the benefits have cascading effects affecting interacting species (e.g., predators, parasites, mutualistic partners). For instance, fire attracts many insects (e.g., bark beetles, saproxylic insects) that are the food of many birds (e.g., Hovick et al. 2017). Additional examples can be obtained from reviews like those in North America (Smith 2000) or in Australia (Whelan et al. 2002)

References [1] Lopes and Vasconcelos (2011), [2] Romme et al. (2011), [3] Andersen (1988), [4] Gibbons and Lindenmayer (2002), [5] Boucher et al. (2012), [6] Koivula et al. (2006), [7] Kiltie (1989), [8] Evans (1966), [9] Evans (2010), [10] Klocke et al. (2011), [11] Jacobs et al. (2011), [12] Bernhardt (1990), [13] Fulton and Carpenter (1979), [14] Prada et al. (1995), [15] Potts et al. (2003), [16] Contreras Mart'́nez and Santana (1995), [17] Jaffe and Isbell (2009), [18] Hancock et al. (2011), [19] Parr et al. (2006), [20] Christian and Morton (1992), [21] Scasta (2015), [22] Howard and Hill (2007), [23] Pausas et al. (unpublished)

conditions generated by fire, and thus, dependent on a given fire regime (fire-dependent animals). In many cases, drivers other than fire, like human disturbances (e.g., clearing), can generate similar habitats and responses, however here we focus principally on cases in natural settings, where these conditions are mostly generated by wildfires (and in some cases, by prescribed fires too). 
Some animals are directly killed by fire (by either heat or smoke), but it is generally thought that many escape from it by moving to safe sites. Because the postfire environment differs strongly to prefire conditions, some animals substantially alter their diet and behavior after fire (e.g., Stawski et al. 2015; O’Donnell et al. 2016). Other species can be negatively affected due to either starvation or increased predation in open conditions (indirect fire effects; e.g. Leahy et al. 2016). Fire-related mortality and the degree of habitat structural change largely depend on the characteristics of the fire (intensity, season, extent, patchiness); for example, high intensity crown-fires usually cause greater changes in the habitat and faunal communities than low intensity surface fires (see Smith 2000 for examples).

Among the animals that require habitat created by fires, there are those species that inhabit open conditions or large forest gaps (Table 2); these include large mammalian herbivores that feed on new high quality vegetation regrowth after fires. Many large herbivores are adapted to the grassy environment provided in flammable open habitats (Parr et al. 2014; Bowman et al. 2016) (e.g., tropical savanna, tallgrass prairies), and easily coexist and interact with the surface fires occurring in these ecosystems (Fuhlendorf et al. 2009). Although in many instances the benefits have not usually been framed in terms of fitness, there are exceptions. For instance, the availability of postfire regrowth in the early dry season has been shown to be help sable antelope (Hippotragus niger) cope with the nutritional limits posed by the dry season, and is especially critical to lactating females (Parrini and Owen-Smith 2010). The evolution of some diets in animals (C4 diet specialists, e.g., grasses and sedges) has been linked to the evolution and spread of fire-prone grassy ecosystems (Edwards et al. 2010). In addition, herbivores may also modify fire regimes themselves (Pausas and Keeley 2014), and in some cases, there may be feedback processes between fire and animals in such a way that animals generate fire regimes more appropriate for their survival (niche construction); this includes large herbivores that maintain tree-grass ecosystems (van Langevelde et al. 2003), and animals that by removing litter, inhibit surface fires around them (e.g. ants and some ground-nesting birds, Carvalho et al. 2012; Nugent et al. 2014; Smith et al. 2017). Given that many parasites, including ticks, have a life stage in the vegetation, fire can also benefit some vertebrates by killing parasites and reducing the spread of diseases (Scasta 2015). Thus, the post-fire period can provide a window of health and opportunity for many vertebrates.

Some animals using the post-fire environment are opportunistic species that are widely distributed, while others are highly specialized to postfire conditions and seldom occur outside burned areas. For instance, there are many insects living in dead wood or weakened trees that benefit from (or depend on) fire and respond positively by increasing their populations after fire (Table 2). In fact, some populations of fire-dependent saproxylic insects have been reduced in northern Europe due to the suppression of natural fires from managed forests; prescribed burns are now being used as management strategy to aid their conservation (e.g., Wikars 2002). Among vertebrates, there are some emblematic examples of fire-dependent birds in different environments, including the black-backed woodpecker (Picoides articus) that inhabits severely burned coniferous forest of North America (Collard 2015); it feeds on wood-boring beetle larvae and nests in trees recently killed by fire. That is, fires may favour some species (e.g., the beetles in this case) and have positive cascading effects on other trophic levels (predators; Hovick et al. 2017) and interacting species. Other emblematic examples of fire-dependent animals include the migratory hummingbirds in tropical ecosystems that depend on post-fire flowers (Contreras Mart' inez and Santana 1995), or grouse (Tetrao species) that require open gaps in the boreal forest for mating (Hancock et al. 2011). Frill-necked lizards (Chlamydosaurus kingii) of northern 
Australia occur at higher densities and have higher body mass on burnt as opposed to unburnt sites, because of greater prey accessibility (Corbett et al. 2003). Feral cats have been shown to travel long-distances to reach intensely burnt habitats where food is easier to detect (McGregor et al. 2016). Small prey must balance their increased risk of predation against the benefit of available resources (e.g. new plant shoots) in the burned area. The altered conditions postfire (light, soil nutrient availability, enhanced seed germination) often result in a bloom of flowers shortly after fire that benefits pollinators (e.g., Bernhardt 1990; Contreras Mart' inez and Santana 1995; Potts et al. 2003). This increase in pollination is likely to also benefit predators (Hovick et al. 2017; cascading effects), and to affect the whole structure of the web of interactions, but little research has been performed at this scale in postfire conditions.

There are other animals that appear to benefit from specific postfire successional stages; many are from forested environments were changes to the habitat following fire persist much longer than in grassy systems (e.g. savannas). Vegetation structure is a classical niche dimension (MacArthur and MacArthur 1961). There are many studies across a range of taxonomic groups documenting successional replacement of species over several decades as habitat changes following a fire (for a classical example, Fox 1982). Similarly, there are a number of studies reporting different animal communities depending on the different vegetation structure determined by different fire regimes. While many species may do well across different stages, in some cases the specialization is particulary strong. An iconic example is the Leadbeater's possum (Gymnobelideus leadbeateri) that was very rare in Australia and thought to have gone extinct after the extensive 1939 Black Friday fires burned their entire distribution range (Gibbons and Lindenmayer 2002). However, forest regrowth provided food, and large dead trees left still standing after the fires provided shelter and nesting allowing the Leadbeater's possum population to greatly expand from prefire conditions (Gibbons and Lindenmayer 2002). No obvious adaptation to survive fire can be seen in this creature, yet their habitat requirements are only provided by the occurrence of large infrequent fire. The existence of species adapted to different vegetation structures or to a mix of different postfire successional stages provides conservation value to landscape mosaic of different postfire age and has led to the use of "patch mosaic burning" for conservation (e.g., Legge et al. 2015; Berry et al. 2016). It is also the base of the idea that "pyrodiversity begets biodiversity" (Martin and Sapsis 1992; Parr and Andersen 2006; Bowman et al. 2016).

While some species can benefit from the habitat generated by recurrent fires, other animals also benefit from the fire itself, i.e., directly as it is occurring. It is common, for example, to see birds of prey (e.g., Bonta et al. 2017) and other opportunistic species (e.g., fork tailed drongos, Dicrurus adsimilis, in Africa; C.L. Parr, pers. observ.) catching insects fleeing the fire front, while other bird species (e.g., white storks, Ciconia ciconia; Corbett et al. 2003; and different egrets species, J.G. Pausas, pers. observ.) walk behind the fire feeding on recently charred invertebrates (fire-foranging). There is even some evidence of raptors intentionally spreading fire for increasing the availablility of preys (Bonta et al. 2017). However, the contribution of this food source to their diet and survival during the dry season remains to be quantified (Table 1). Insects that have fire detectors and are attracted to the flames also benefit directly from fire (Schutz et al. 1999; Evans 2010; seebelow).

Overall there are many species that, in one way or other, are dependent on particular fire regimes for completing their life cycle. These species may not show any apparent fire adaptation, but almost certainly they would become very rare or even extinct in the absence of fires generating their habitat. Species in open fire-prone habitats may not necessarily be adapted to fire but to landscapes or biomes generated under a certain fire regime. In short, 
we cannot imagine the great diversity of many open ecosystems, including the fauna they contain, without the existence of fires. This begs the question: to what extent do some of these animals show specific fire adaptations? This is relevant for understanding the evolutionary pressures shaping diversity, and has implications for land and fire management. Below we review evidence of putative adaptations to (a) survive fire, and (b) to survive and exploit postfire conditions.

\section{On the search for fire adaptations in animals}

\section{Dealing with fire: fire survival adaptations}

Many plants in fire-prone ecosystems persist after a fire thanks to morphological adaptive traits conferring survival (e.g., thick bark and resprouting structures; Keeley et al. 2012; Pausas 2015; Pausas et al. 2018). This is not necessary true for animals; their mobility and general lack of modularity means that behavioral traits are more likely to evolve. Because the direct fire impact is often detrimental to animals, developing or enhancing behaviors to rapidly detect fires (e.g., from the smoke or sound) and escape from them could be adaptive in recurrently burned ecosystems. However, it is not always easy to discern the role of fire from the role of predators in shaping those behaviors. Examples of fire-related behavior include the evidence that some bats and possums can detect smoke even when in torpor, and thus they arouse and move to a safe site (Scesny and Robbins 2006; Nowack et al. 2016). Behaviours that allow detection and avoidance of fire are especially important in less-mobile animals (Whelan 1995); for instance, some frogs appears to recognize the sound of fire and quickly move to less flammable habitats (Grafe et al. 2002). Newts have been observed rapidly crossing fire fronts to move to unburnt refuges; apparently, their skin secretion facilitates their survival (Stromberg 1997). Terrestrial tortoises are abundant in some fire-prone ecosystems (Ernst et al. 1995; Sanz-Aguilar et al. 2011); yet, little is known about their ability to detect fire and move to refuges (ground holes, bare patched), or to what extent recurrent fire may have selected for some morphological traits to increased protection. Some Australian lizards make use of holes in the soil for shelter in frequently burnt habitats but do not use them in habitats that experience lower fire frequencies (Braithwaite 1987). Many non-flying invertebrates (e.g. ants, stick insects, wingless nymphs of grasshoppers, spiders) appear to be able to detect fires well in advance of the front, presumably from smoke or sound; they attempt to shelter from fires by either moving into the soil, or by climbing to the tops of trees (Sensenig et al. 2017; Dell et al. 2017). Some animals in fire-prone ecosystems do not appear to show stressed behaviour in the presence of fire, but move calmly and search for a safe site or for a low flammability patch (Whelan 1995). Outstanding examples are the case of primates, including chimpanzees (Pan troglodytes), which through a complex suite of behaviours to avoid fire, including observing and predicting fire behavior, communicate to each other about the fire's occurrence, and move accordingly without showing sings of stress (Pruetz and LaDuke 2010). And after fire, they expand their home range to the burned area for food gathering, including eating "cooked" fruits (Herzog et al. 2014). Another putative behavioral adaptation is the case of those animals that evade the fire by actively excluding it, as some ants or the Australian lyrebird that, by consuming or moving litter, they inhibit surface fires around their nests (Carvalho et al. 2012; Nugent et al. 2014). Some species can enter torpor as food availability decreases and the exposure to predators increases postfire; this may also provide benefits in postfire conditions where resources are low. This is the 
case of some small mammals that do not leave their home range after fire but remain hidden and reduce their activity by lowering their body temperature and increasing multiday torpor (Stawski et al. 2015).

To what extent fire has contributed to shaping all these escape-avoiding behaviors in animals is unclear because most studies have not been framed in terms of fitness benefits (Tables 1, 3). It is likely that fire acts as a selection pressure in many of these animal behaviors, in a similar way to other changes in enemy pressure. For example, animals living on islands are less wary than those on the mainland, presumably because of the lack of predators (Cooper et al. 2014). Even over a short time scale, many animals modify their behavior in response to recent changes in predators (e.g., Samia et al. 2015; Geffroy et al. 2015; Mikolajewski et al. 2016; Dröge et al. 2017). Despite animal behavior being the product of multiple selective pressure (as many other traits), species living under long contact with fires may have evolved particular behaviours to increase fire survival (Table 3). The search for mechanisms driving putative fire adaptations in the animal kingdom is an open research area (Tables 1, 3).

Table 3 Examples of traits that may be adaptive for animals living in fire-prone ecosystems, and thus they are candidate traits that could be modified by natural selection (i.e., fine-tuned by fire) or could be overrepresented, in fire-prone ecosystems

\begin{tabular}{|c|c|c|}
\hline Trait & Type & Examples [references] \\
\hline $\begin{array}{l}\text { Ability to make a hole for } \\
\text { protection }\end{array}$ & Behavioral & Small mammals, large arthropods \\
\hline $\begin{array}{l}\text { Ability to use a shelter for } \\
\text { protection }\end{array}$ & Behavioral & Reptiles [1] \\
\hline $\begin{array}{l}\text { Ability to modify fuel } \\
\text { continuity }\end{array}$ & Behavioral & Ground-dwelling birds $[29,30]$ \\
\hline Burrowing live & Behavioral & Arthropods [28], reptiles \\
\hline Non-panicked response & Behavioral & Primates [5], other mammals \\
\hline Nesting deeper in the soil & Behavioral & Arthropods [28], reptiles \\
\hline Ability to move long-distance & Behavioral & Mammalian predators [6] \\
\hline Fire detection & $\begin{array}{l}\text { Behavioral/ } \\
\text { Morphological }\end{array}$ & Vertebrates [2-4] \\
\hline Fire detectors & Morphological & Arthropods: beetles [7-13], ants [31] \\
\hline Protective cover to body & Morphological & Tortoises [14-17], snails [25], newts [18] \\
\hline Dark (cryptic) colour & Morphological & $\begin{array}{l}\text { Lizards [19], mammals [20, 21], arthropods } \\
\text { [22-24], birds (eggs) }\end{array}$ \\
\hline Ability to enter in torpor & Physiological & Mammals $[4,26]$ \\
\hline Thermophilia & Physiological & Ants [27] \\
\hline
\end{tabular}

Most traits confer survival during fire, except the last three traits that confer survival in postfire conditions. Examples of animal groups in which these traits could appear are also given. These traits and species groups require further research in an evolutionary context (Table 1)

References [1] Braithwaite (1987), [2] Grafe et al. (2002), [3] Scesny and Robbins (2006), [4] Nowack et al. (2016), [5] Pruetz and LaDuke (2010), [6] Lillywhite et al. (1977), [7] Álvarez et al. (2015), [8] Evans (1966), [9] Evans (2010), [10] Klocke et al. (2011), [11] Milberg et al. (2015), [12] Schmitz and Trenner (2003), [13] Suckling et al. (2001), [14] Ernst et al. (1995), [15] Platt et al. (2010), [16] Sanz-Aguilar et al. (2011), [17] Rodr' iguez-Caro et al. (2013), [18] Stromberg (1997), [19] Lillywhite et al. (1977), [20] Guthrie [(1967), [21] Kiltie (1989), [22] Forsman et al. (2011), [23] Karlsson et al. (2008), [24] Karpestam et al. (2012), [25] Kiss and Magnin (2006), [26] Stawski et al. (2015), [27] Christian and Morton (1992), [28] Thom et al. (2015), [29] Nugent et al. (2014), [30] Smith et al. (2017), [31] Sensenig et al. (2017) 


\section{Adapting to survive and exploit postfire environments}

There are some cases in which we find evidence of specific adaptations to survive the new environment or to exploit the newly available resources, and in this includes some morphological adaptations (Table 3). Perhaps the best-documented adaptation to fire in the animal kingdom is the presence of fire detectors in a number of insect species (Schutz et al. 1999; Evans 1966, 2010). This is not an adaptation to avoid fires but rather enables them to locate them and make use of new resources in the postfire environment. These pyrophilic insects are attracted to the flames of fires, often mate close to the fire (fire as a meeting point), lay eggs in killed or weakened trees, and their larvae feed on burned wood (specifically, fungi in burned logs) or on the phloem of weakened trees. The classical examples are the pyrophilous beetles of the genus Melanophila (Buprestidae, Coleoptera) that have infrared receptors (e.g., Schutz et al. 1999) and those of the Cerambycidae family (Coleoptera) that have smoke receptors (Table 2), although there are many other insects with a pyrophilous behavior from a range of taxonomic groups (Table 2). There are also some insects that remain dormant for several years in the soil as larvae, and when a fire occurs, it stimulates a synchronized emergence (Jacobs et al. 2011); to what extent this synchronization has been selected by fire remains unexplored, but it could be adaptive in fire-prone environments.

After a fire, in addition to changes in vegetation structure, the colour of the habitat alters dramatically too. Thus, another common adaptation of animals living in fire prone ecosystems, and especially animals that use recently burnt environments, is the development of cryptic colouration that provides camouflage in the new environment (Table 3). Dark colouration confers a selective benefit mediated by enhanced camouflage in recently burned areas (Forsman et al. 2011). For instance, the flightless Greater rhea (Rhea americana) that lives in the South American savannas (cerrado) subject to very frequent fires (i.e., several fires per decade), has a long neck with a black base; when it sits on the ground, it cannot be differentiated from a burnt stem. Similarly, in Africa there are several bird species that use recently burned ground for breeding (e.g. coursers, plovers, larks and night-jars): eggs are dark coloured and chicks possess heavily pigmented down, providing camouflage in postfire conditions (de Ronde et al. 2004). The Californian lizard (Sceloporus occidentalis) is also cryptically coloured matching the black stalks on burned shrubs (Lillywhite et al. 1977), and the abundance of melanic squirrels in North America is positively correlated with the fire frequency (fire melanism; Guthrie 1967; Kiltie 1989). Invertebrates too show colour modifications to increase fitness postfire; for example, the frequency of melanistic individuals of the pygmy grasshopper (Tetrix subulata) is higher after fire (predation is reduced) than in unburned areas (where they are more conspicuous). In this case, and given that grasshoppers complete their life cycle within a year, the proportion of melanistic individuals declines as vegetation recovers and ground cover changes; thus, under frequent fires, they show fluctuating selection associated to the fire (Forsman et al. 2011).

\section{Concluding remarks}

Plants have been the main focus for research on the evolution of fire-prone ecosystems, however, there remain great challenges and opportunities for studying the relation between fire and fauna in an evolutionary framework. Many animal species show a preference, 
sometimes strongly, for habitats generated by fire (fire-dependent fauna), but few of them show specific adaptations facilitating fire or postfire survival (fire-adapted fauna). In part this may simply reflect the low number of studies that have attempted to look for adaptations. There remains significant scope for research on fire adaptations in animals, and especially in relation to the rich behavioral traits that allow persistence in fire-prone ecosystems (Tables 1, 3). These traits are poorly explored under the framework of the evolutionary fire ecology but may provide a rich source of fire adaptations. Discerning adaptations to fire survival from those adaptations to fire-generated habitats may provide clues on the mechanism generating biodiversity, and keys for land management. There is much to be done to unambiguously disentangle the evolutionary role of fire in animalswe are hopeful this paper will stimulate future research.

Acknowledgements This research was funded by the project FILAS (CGL2015-64086-P) from the Spanish Government (Ministerio de Econom' 1a y Competitividad) and the PROMETEO/2016/021 project from the Valencia government (Generalitat Valenciana, Spain). CIDE (Desertification Research Centre) is a joint institute of the Spanish National Research Council (CSIC), the University of Valencia, and Generalitat Valenciana. J.G.P. conceived the idea and wrote the manuscript; C.L.P. contributed to the writing of the final version. We declare no conflict of interest.

\section{References}

Álvarez G, Ammagarahalli B, Hall DR, Pajares JA, Gemeno C (2015) Smoke, pheromone and kairomone olfactory receptor neurons in males and females of the pine sawyer Monochamus galloprovincialis (Olivier) (Coleoptera: Cerambycidae). J Insect Physiol 82:46-55

Andersen AN (1988) Immediate and longer-term effects of fire on seed predation by ants in sclerophyllous vegetation in south-eastern Australia. Aust J Ecol 13:285-293

Bernhardt P (1990) Pollination ecology of Oxalis violacea (Oxalidaceae) following a controlled grass fire. Plant Syst Evol 171:147-155

Berry LE, Lindenmayer DB, Dennis TE, Driscoll DA, Banks SC (2016) Fire severity alters spatio-temporal movements and habitat utilisation by an arboreal marsupial, the mountain brushtail possum (Trichosurus cunninghami). Int J Wildland Fire 25:1291-1302

Bonta M, Gosford R, Eussen D, Ferguson N, Loveless E, Witwer M (2017) Intentional fire-spreading by "Firehawk" raptors in Northern Australia. J Ethnobiol 37:700-718

Boucher J, Azeria ET, Ibarzabal J, Hébert C (2012) Saproxylic beetles in disturbed boreal forests: temporal dynamics, habitat associations, and community structure. Ecoscience 19:328-343

Bowman DMJS, Perry GLW, Higgins SI, Johnson CN, Fuhlendorf SD, Murphy BP (2016) Pyrodiversity is the coupling of biodiversity and fire regimes in food webs. Phil Trans R Soc Lond B Biol Sci 371:20150169

Braithwaite RW (1987) Effects of fire regimes on lizards in the wet-dry tropics of Australia. J Trop Ecol 3:265-275

Carvalho KS, Alencar A, Balch J, Moutinho P (2012) Leafcutter ant nests inhibit low-intensity fire spread in the understory of transitional forests at the Amazon's forest-savanna boundary. Psyche 2012:780713

Chergui B, Fahd S, Santos X, Pausas JG (2018) Socioeconomics drive fire regime variability in the Mediterranean Basin. Ecosystems. https://doi.org/10.1007/s10021-017-0172-6

Christian KA, Morton SR (1992) Extreme thermophilia in a central Australian ant, Melophorus bagoti. Physiol Zool 65:885-905

Collard SB (2015) Fire Birds: valuing natural wildfires and burned forests. Bucking Horse Books, Missoula Contreras Mart' inez S, Santana E (1995) The effect of forest fires on migratory birds in the Sierra de

Manatlan, Jalisco, Mexico. In: Wilson MH, Sader SA (eds) Conservation of neotropical migratory birds in Mexico. Maine Agricultural and Forest Experiment Station, Maine, pp 113-122

Cooper WE, Pyron RA, Garland T (2014) Island tameness: living on islands reduces flight initiation distance. Proc R Soc Lond B Biol Sci 281:20133019. https://doi.org/10.1098/rspb.2013.3019

Corbett LK, Andersen AN, Müller WJ (2003) Terrestrial vertebrates. In: Andersen AN, Cook GD, Williams RJ (eds) Fire in tropical savannas. Springer, New York, pp 126-152 
De Ronde CJ, Trollope WSW, Parr CL, Brockett B, Geldenhuys CJ (2004) Fire effects on flora and fauna. In: Goldammer JG, De Ronde CJ (eds) Wildlife fire management handbook for South Africa. Global Fire Monitoring Centre, Freiburg

Dell J, O’Brien J, Doan L, Richards L, Dyer L (2017) An arthropod survival strategy in a frequently burned forest. Ecology 98:2972-2974

Dröge E, Creel S, Becker MS, M'soka. J (2017) Risky times and risky places interact to affect prey behaviour. Nat Ecol Evol 1:1123-1128

Edwards EJ, Osborne CP, Strömberg CAE, Smith SA, Consortium CG (2010) The origins of C4 grasslands: integrating evolutionary and ecosystem science. Science 328:587-591

Ernst C, Boucher T, Sekscienski S, Wilgenbusch J (1995) Fire cology of the Florida box turtle, Terrapene carolina bauri. Herpet Rev 26:185-186

Evans WG (1966) Perception of infrared radiation from forest fires by Melanophila acuminata de Geer (Buprestidae, Coleoptera). Ecology 47:1061-1065

Evans WG (2010) Reproductive role of infrared radiation sensors of Melanophila acuminata (Coleoptera: Buprestidae) at forest fires. Ann Entomol Soc Am 103:823-826

Forsman A, Karlsson M, Wennersten L, Johansson J, Karpestam E (2011) Rapid evolution of fire melanism in replicated populations of pygmy grasshoppers. Evolution 65:2530-2540

Fox BJ (1982) Fire and mammalian secondary succession in an Australian coastal heath. Ecology 63:13321341

Fuhlendorf SD, Engle DM, Kerby J, Hamilton R (2009) Pyric herbivory: rewilding landscapes through the recoupling of fire and grazing. Conserv Biol 23:588-598

Fulton RE, Carpenter FL (1979) Pollination, reproduction and fire in Arctostaphylos. Oecologia 113:871879

Geffroy B, Samia DSM, Bessa E, Blumstein DT (2015) How nature-based tourism might increase prey vulnerability to predators. Trends Ecol Evol 30:755-765

Gibbons P, Lindenmayer D (2002) Tree hollows and wildlife conservation in Australia. CSIRO Pub, Canberra

Grafe TU, Dö bler S, Linsenmair KE (2002) Frogs flee from the sound of fire. Proc R Soc Lond B Biol Sci 269:999-1003

Guthrie RD (1967) Fire melanism among mammals. Am Midl Nat 77:227-230

Hancock MH et al (2011) Burning and mowing as habitat management for capercaillie Tetrao urogallus: an experimental test. For Ecol Manage 262:509-521

Herzog NM, Parker CH, Keefe ER, Coxworth J, Barrett A, Hawkes K (2014) Fire and home range expansion: a behavioral response to burning among savanna dwelling vervet monkeys (Chlorocebus aethiops). Am J Phys Anthropol 154:554-560

Hovick TJ, McGranahan DA, Elmore RD, Weir JR, Pyric-carnivory Fuhlendorf SD (2017) Raptor use of prescribed fires. Ecol Evol 7:9144-9150

Howard DR, Hill PSM (2007) The effect of fire on spatial distributions of male mating aggregations in Gryllotalpa major Saussure (Orthoptera: Gryllotalpidae) at the nature conservancy’s tallgrass prairie preserve in Oklahoma: evidence of a fire-dependent species. J Kansas Entomol Soc 80:51-64

Jacobs JM, Bergeron JAC, Work TT, Spence JR (2011) Low intensity surface fire instigates movement by adults of Calosoma frigidum (Coleoptera, Carabidae). ZooKeys 174:641-649

Jaffe KE, Isbell LA (2009) After the fire: benefits of reduced ground cover for vervet monkeys (Cercopithecus aethiops). Am J Primatol 71:252-260

Karlsson M, Caesar S, Ahnesjö J, Forsman A (2008) Dynamics of colour polymorphism in a changing environment: Fire melanism and then what? Oecologia 154:715-724

Karpestam E, Merilaita S, Forsman A (2012) Reduced predation risk for melanistic pygmy grasshoppers in post-fire environments. Ecol Evol 2:2204-2212

Keeley JE, Syphard A (2016) Climate change and future fire regimes: examples from California. Geosci 6:37

Keeley JE, Pausas JG, Rundel PW, Bond WJ, Bradstock RA (2011) Fire as an evolutionary pressure shaping plant traits. Trends Plant Sci 16:406-411

Keeley JE, Bond WJ, Bradstock RA, Pausas JG, Rundel PW (2012) Fire in Mediterranean ecosystems: ecology, evolution and management. Cambridge University Press, Cambridge

Kiltie RA (1989) Wildfire and the evolution of dorsal melanism in fox squirrels, Sciurus niger. J Mammal 70:726-739

Kiss L, Magnin F (2006) High resilience of Mediterranean land snail communities to wildfires. Biodiv Conserv 15:2925-2944

Klocke D, Schmitz A, Schmitz H (2011) Fire-adaptation in Hypocerides nearcticus Borgmeier and Anabarhynchus hyalipennis hyalipennis Marquart and new notes about the Australian "Smoke Fly" 
Microsania australis Collart (Diptera: Phoridae, Therevidae and Platypezidae). Open Entomol J 5:10-14

Koivula M, Cobb T, Dechene AD, Jacobs J, Spence JR (2006) Responses of two Sericoda Kirby, 1837 (Coleoptera: Carabidae) species to forest harvesting, wildfire, and burn severity. Entomol Fenn $17: 315-324$

Leahy L et al (2016) Amplified predation after fire suppresses rodent populations in Australia’s tropical savannas. Wildl Res 42:705-716

Legge S et al (2015) A landscape-scale, applied fire management experiment promotes recovery of a population of the threatened Gouldian finch, Erythrura gouldiae, in Australia's tropical savannas. PLOS ONE 10:e0137997

Lillywhite HB, Friedman G, Ford N (1977) Color matching and perch selection by lizards in recently burned chaparral. Copeia 1977:115-121

Lopes CT, Vasconcelos HL (2011) Fire increases insect herbivory in a Neotropical savanna. Biotropica 43:612-618

MacArthur RH, MacArthur JW (1961) On bird species diversity. Ecology 42:594-598

Martin RE, Sapsis DB (1992) Fires as agents of biodiversity: pyrodiversity promotes biodiversity. In: Kerner HM (ed) Proceedings of the conference on biodiversity of northwest California. University of California, Berkeley, pp 150-157

McGregor HW, Legge S, Jones ME, Johnson CN (2016) Extraterritorial hunting expeditions to intense fire scars by feral cats. Sci Rep 6:22559

Mikolajewski DJ, Scharnweber K, Jiang B, Leicht S, Mauersberger R, Johansson F (2016) Changing the habitat: the evolution of inter-correlated traits to escape from predators. J Evol Biol 29:1394-1405

Milberg P, Bergman K-O, Norman H, Pettersson R, Westerberg L, Wikars L-O, Jansson N (2015) A burning desire for smoke? Sampling insects favoured by forest fire in the absence of fire. J Insect Conserv 19:55-65

New TR (2014) Insects, fire and conservation. Springer, New York

Nowack J, Delesalle M, Stawski C, Geiser F (2016) Can hibernators sense and evade fires? Olfactory acuity and locomotor performance during deep torpor. Sci Nat 103:1-7

Nugent DT, Leonard SWJ, Clarke MF (2014) Interactions between the superb lyrebird (Menura novaehollandiae) and fire in south-eastern Australia. Wildl Res 41:203-211

O’Donnell KM, Thompson FR, Semlitsch RD (2016) Prescribed fire alters surface activity and movement behavior of a terrestrial salamander. J Zool 298:303-309

Parr CL, Andersen AN (2006) Patch mosaic burning for biodiversity conservation: a critique of the pyrodiversity paradigm. Conserv Biol 20:1610-1619

Parr CL, Chown SL (2003) Burning issues for conservation: a critique of faunal fire research in Southern Africa. Austral Ecol 28:384-395

Parr CL, Andersen AN, Chastagnol C, Duffaud C (2006) Savanna fires increase rates and distances of seed dispersal by ants. Oecologia 151:33-41

Parr CL, Lehmann CER, Bond WJ, Hoffmann WA, Andersen AN (2014) Tropical grassy biomes: misunderstood, neglected, and under threat. Trends Ecol Evol 29:205-213

Parrini F, Owen-Smith N (2010) The importance of post-fire regrowth for sable antelope in a Southern African savanna. Afr J Ecol 48:526-534

Pausas JG (2015) Bark thickness and fire regime. Funct Ecol 29:315-327

Pausas JG, Keeley JE (2009) A burning story: the role of fire in the history of life. Bioscience 59:593-601

Pausas JG, Keeley JE (2014) Abrupt climate-independent fire regime changes. Ecosystems 17:1109-1120

Pausas JG, Bradstock RA, Keith DA, Keeley JE (2004) Plant functional traits in relation to fire in crown-fire ecosystems. Ecology 85:1085-1100

Pausas JG, Lamont BB, Paula S, Appezzato-da-Gló ria B, Fidelis A (2018) Unearthing belowground bud banks in fire-prone ecosystems. New Phytol. https://doi.org/10.1111/nph.14982

Platt SG, Liu H, Borg CK (2010) Fire ecology of the Florida box turtle (Terrapene carolina bauri Taylor) in Pine Rockland Forests of the lower Florida Keys. Nat Areas J 30:254-260

Potts SG et al (2003) Response of plant-pollinator communities to fire: changes in diversity, abundance and floral reward structure. Oikos 101:103-112

Prada M, Marini-Filho OJ, Price PW (1995) Insects in flower heads of Aspilia foliacea (Asteraceae) after a fire in a central Brazilian savanna: evidence for the plant vigor hypothesis. Biotropica 27:513-518

Pruetz JD, LaDuke TC (2010) Reaction to fire by savanna chimpanzees (Pan troglodytes Verus) at Fongoli, Senegal: conceptualization of "fire behavior" and the case for a chimpanzee model. Am J Phys Anthropol 141:646-650

Rodríguez-Caro R, Graciá E, Anadón J, Gimenez A (2013) Maintained effects of fire on individual growth and survival rates in a spur-thighed tortoise population. Eur J Wildl Res 59:911-913 
Romme WH, Boyce MS, Gresswell R, Merrill EH, Minshall GW, Whitlock C, Turner MG (2011) Twenty years after the 1988 yellowstone fires: lessons about disturbance and ecosystems. Ecosystems 14:1196-1215

Samia DSM, Nakagawa S, Nomura F, Rangel TF, Blumstein DT (2015) Increased tolerance to humans among disturbed wildlife. Nat Commun 6:8877

Sanz-Aguilar A, Anadó n JD, Giménez A, Ballestar R, Graciá E, Oro D (2011) Coexisting with fire: the case of the terrestrial tortoise Testudo graeca in mediterranean shrublands. Biol Conserv 144:1040-1049

Scasta JD (2015) Fire and parasites: an under-recognized form of anthropogenic land use change and mechanism of disease exposure. EcoHealth 12:398-403

Scesny AA, Robbins LW (2006) Detection of fire by eastern red bats (Lasiurus borealis): arousal from torpor. Bat Res News 47:142

Schmitz H, Trenner S (2003) Electrophysiological characterization of the multipolar thermoreceptors in the "fire-beetle'" Merimna atrata and comparison with the infrared sensilla of Melanophila acuminata (both Coleoptera, Buprestidae). J Comp Physiol A 189:715-722

Schoennagel T, Balch JK, Brenkert-Smith H, Dennison PE, Harvey BJ, Krawchuk MA, Mietkiewicz N, Morgan P, Moritz MA, Rasker R, Turner MG, Whitlock C (2017) Adapt to more wildfire in western North American forests as climate changes. Proc Natl Acad Sci USA 114:4582-4590

Schutz S, Weissbecker B, Hummel HE, Apel KH, Schmitz H, Bleckmann H (1999) Insect antenna as a smoke detector. Nature 398:298-299

Sensenig RL, Kimuyu DK, Ruiz Guajardo JC, Veblen KE, Riginos C, Young TP (2017) Fire disturbance disrupts an acacia ant-plant mutualism in favor of a subordinate ant species. Ecology 98:1455-1464 Smith JK (ed) (2000) Wildland fire in ecosystems: Effects of fire on fauna. General Technical Report RMRS-GTR-42, Rocky Mountain Research Station, USDA Forest Service

Smith A, Avitabile SC, Leonard SWJ (2017) Less fuel for the fire: malleefowl (Leipoa ocellata) nesting activity affects fuel loads and fire behaviour. Wildl Res 43:640-648

Stawski C, Körtner G, Nowack J, Geiser F (2015) The importance of mammalian torpor for survival in a post-fire landscape. Biol Lett 11:20150134

Stromberg M (1997) Taricha torosa (California newt) response to fire. Herpetol Rev 28:82-84

Suckling DM, Gibb AR, Daly JM, Chen X, Brockerhoff EG (2001) Behavioral and electrophysiological responses of Arhopalus tristis to burnt pine and other stimuli. J Chem Ecol 27:1091-1104

Swengel A (2001) A literature review of insect responses to fire, compared to other conservation managements of open habitat. Biodivers Conserv 10:1141-1169

Thom MD, Daniels JC, Kobziar LN, Colburn JR (2015) Can butterflies evade fire? Pupa location and heat tolerance in fire prone habitats of Florida. PLoS ONE 10:e0126755

van Langevelde F, Van de Vijver CADM, Kumar L, van de Koppel J, Ridder N, van Andel J, Skidmore AK, Hearne JW, Stroosnijder L, Bond WJ, Prins HHT, Rietkerk M (2003) Effects of fire and herbivory on the stability of savanna ecosystems. Ecology 84:337-350

van Mantgem EF, Keeley JE, Witter M (2015) Faunal responses to fire in chaparral and sage scrub in California, USA. Fire Ecol 11:128-148

Whelan RJ (1995) The ecology of fire. Cambridge University Press, Cambridge

Whelan R, Rodgerson L, Dickman CR, Sutherland EF (2002) Critical life cycles of plants and animals: developing a process-based understanding of population changes in fire-prone landscapes. In: Bradstock RA, Williams JE, Gill AM (eds) Flammable Australia: the fire regimes and biodiversity of a continent, pp 94-124

Wikars L-O (2002) Dependence on fire in wood-living insects: an experiment with burned and unburned spruce and birch logs. J Insect Conserv 6:1-12 